\title{
IAMJ
}

INTERNATIONAL

AYURVEDIC

MEDICAL JOURNAL

Case Report

ISSN: 23205091

Impact Factor: 5.344

\section{EFFECT OF PERINEAL REPAIR AND MUSHAKADI TAILA MATRABASTI IN MANAGEMENT OF RECTAL PROLAPSE (GUDABHARMSA): A CASE STUDY}

\author{
Sapna Maheshwari' ${ }^{1}$, Harshit Shah ${ }^{2}$, PragneshPatel ${ }^{3}$ \\ ${ }^{1}$ P.G. Scholar, ${ }^{2}$ Professor and H.O.D, 3Lecturer \\ Department of Shalya Tantra, Govt. Akhandanad Ayurved College, Ahmedabad, Gujarat, India
}

Corresponding Author: sapnaamaheshwari23@gmail.com

https://doi.org/10.46607/iamj3808082020

(Published online: August 2020)

Open Access

(C) International Ayurvedic Medical Journal, India 2020

Article Received: 23/07/2020 - Peer Reviewed: 05/8/2020 - Accepted for Publication: 05/08/2020

Check for updates

\section{ABSTRACT}

Rectal prolapse can present in a variety of forms and is associated with a range of symptoms including pain, incomplete evacuation, bloody and/or mucous rectal discharge, and fecal incontinence or constipation. Complete external rectal prolapse is characterized by a circumferential, full-thickness protrusion of the rectum through the anus, which may be intermittent or may be incarcerated and poses a risk of strangulation. There are multiple surgical options to treat rectal prolapse, and thus care should be taken to understand each patient's symptoms, bowel habits, anatomy, and pre-operative expectations. We propose an algorithm based on available outcomes data in the literature, an understanding of ano-rectal physiology, and expert opinion that can serve as a guide to determining the rectal prolapse operation that will achieve the best possible postoperative outcomes for individual patients. Mushakadi Taila Matrabasti will be given in Sushrut Samhita as a treatment ${ }^{1}$ with perineal repair. So, it is really needed to find a safe, easier, less complicating, cost effective and fruitful approach for the management of disease through Ayurveda. A 62year old male patient came to the hospital with chief complaints of protrusion of mass from the anus with mucous discharge, constipation since last 5 years. He was diagnosed as complete rectal prolapse. Considering the signs and symptoms of rectal prolapse, the treatment of rectal prolapsed was planned with perineal repair and Mushakadi Taila Matarabasti as per mentioned in the treatment of Gudabhransha by Aacharya Sushruta. 
Keywords: Rectal prolapse, Management Surgery, Perineal repair, Gudabhransha, Mushakadi Taila

\section{INTRODUCTION}

Rectal prolapse is a full-thickness protrusion of the rectum through the anus.Both complete rectal prolapse and internal intussusception can occur independently or can be associated with the descent and dysfunction of other pelvic organs, e.g. rectoceles, uterine or vaginal vault prolapse, cystocele, or enterocele. The prevalence of external rectal prolapse is relatively low and estimated to occur in less than $0.5 \%$ of the general population overall. ${ }^{2}$ It occurs more frequently in the elderly population and in females; an estimated $3 \%$ of women in the united states have some form of pelvic organ prolapse, including rectal prolapse or uterine or vaginal prolapse, rectocele, cystocele, urethrocele and enterocele. $^{3}$

\section{Case Report}

A 62 years old Hindu male patient residing in Laldarwaja (Ahmedabad) came to OPD of Shalya Department of Govt. Akhandanand Ayurveda College\& Hospital, Bhadra Ahmedabad, on 30 Dec, 2019; with the following complains

Table 1: Chief Complaints

\begin{tabular}{|l|l|l|}
\hline Sr No. & Chief complaints (Present history) & Time duration \\
\hline 1 & Protrusion of mass from anus during defecation & 5 years \\
\hline 3 & Protrusion of mass from anus during standing or coughing & 5 years \\
\hline 4 & Mucous discharge constipation & 5 years \\
\hline
\end{tabular}

\section{History of Present Illness}

Patient was asymptomatic before 5 years. Then gradually he had developed protrusion of mass from anus. He had felt protrusion of mass from anus during defecation, standing and coughing with mucous discharge and constipation. So, for proper treatment he came here in our hospital.

Past History: - No relevant past history was found.

Treatment History: -Patient had not taken any kind of medication

Nidana Found in The Patient

Aaharaj Nidana :- Ruksha, Shita, Katu AaharaSevana

ViharajNidana :-Atipravahana
Family History: no history of rectal prolapse

Ayurvedic Management, Karma - Perineal repair followed by Mushakadi Taila Matrabasti

Perineal repair Repositioning of Guda ${ }^{4}$ - The protruded rectum is pushed inside in its normal position after oleation and sudation, after that GophanaBandha (Tbandage) is done. The GophanaBandha is having an opening in the center for the smooth passage of flatus. Mushakadi Taila in Gudabhransha

Snehana - It can be done internally and externally using Taila. We used here Mushakadi TailaMatrabasti $60 \mathrm{ml} /$ day given for 30 days

Table 2: Treatment Schedule Chart

\begin{tabular}{|l|l|l|}
\hline Date & Procedure & Observations \\
\hline $30 / 12 / 2019$ & $\begin{array}{l}\text { Perineal repair done with Gophan- } \\
\text { aBandha }\end{array}$ & Protrusion of mass from anus is cured with this \\
\hline $\begin{array}{l}31 / 12 / 2019 \\
29 / 01 / 2020\end{array}$ to & $\begin{array}{l}\text { MatraBasti with Mushakadi taila } \\
60 \mathrm{ml} \text { on OPD level }\end{array}$ & $\begin{array}{l}\text { Constipation is relived, no protrusion of rectum during defeca- } \\
\text { tion, standing and coughing, less mucous discharge }\end{array}$ \\
\hline
\end{tabular}




\section{Assessment}

Table 3: Constipation

\begin{tabular}{|l|l|}
\hline 0 & No \\
\hline 1 & Defecation on straining \\
\hline 2 & Hard stool passage \\
\hline 3 & Defecation only after medication \\
\hline Abdominal pain & No pain \\
\hline 0 & Pain but not affecting attendance \\
\hline 1 & Pain reported by him/herself \\
\hline 2 & Retained at home due to pain from work \\
\hline 3 & \\
\hline Secretion & No \\
\hline 0 & Present only during defecation \\
\hline 1 & Occasional mopping of undergarments \\
\hline 2 & Continuous mopping of undergarments \\
\hline 3 & \\
\hline Prolapse mass & $0-1 \mathrm{~cm}$ \\
\hline 0 & $0-1 \mathrm{~cm}$ \\
\hline 1 & $2-3 \mathrm{~cm}$ \\
\hline 2 & $3-4 \mathrm{~cm}$ \\
\hline 3 & \\
\hline
\end{tabular}

\begin{tabular}{|l|l|l|}
\hline & BT & AT \\
\hline Prolapse mass & 2 & 0 \\
\hline Constipation & 3 & 0 \\
\hline Abdominal pain & 2 & 0 \\
\hline Secretion & 3 & 1 \\
\hline
\end{tabular}

\section{DISCUSSION}

Acharyasushruta mentioned rectal prolapse as a Gudabhransha under Kusdraroga. Atipravahana and Vibandha are the main causative factors for Gudabhrmasa as Acharya Sushruta mentioned in Kusdraroga nidana. In modern medical science they give also same causative factors for the rectal prolapse. They give the treatment rectopexy and other surgical treatment for rectal prolapse. In Ayurveda perineal repair is given in Astanga Hridya. In perineal repair reposition of protruded part of rectum had fixed to the presacral fascia with suturing by vicryl 2-0. After that Gophana Bandha is done with remaining small passage to pass the flatus. And after this Mushkadi Taila Matrabasti was given as mentioned in SushrutaSamhita. Mushkadi taila has property to give strengthening of pelvic floor muscles. Muscles around the rec- tum and anal canal have a good grip on rectum after Matrabasti of mushkadi taila. After one month of Matrabasti patient had complete remission of rectal prolapse.

\section{CONCLUSION}

There are many types of Karmas described in the treatment of Gudabhransha like Senhana internally and externally, Swedana like Avagahasweadana, Vatashamaka and Agnideepana treatment orally, Pichu etc. In this case perineal repair with Gophana Bandha and followed by Mushakadi Tail Matrabasti was preferred and complete remission of the disease was obtained. 


\section{REFERENCES}

1. AcharyaSushruta. Chikitsasthana20/61SushrutaSamhita, Kaviraja Ambikadutta Shastri, published by Chaukahmbha Sanskrit Sansthan Varanasi.

2. Kairaluoma MV and Kellokumpu IH. Epidemiologic aspects of complete rectal prolapse. Scand J surg 94:3:207-210,2005

3. Nygaard I, Barber MD, Burgio KL, Kenton K, Meikle S, Schaffer J, Spino C, Whitehead WE, Wu J, Bordy DJ, and pelvic floor disorders network. Prevalence of symptomatic pelvic floor disorders in US women. JAMA 300:11:1311-1316,2008

4. AcharyaVagbhatt. chikitsasthana9/52 Astanga Hridayama, Kaviraja Ambikadutta Shastri, published by Chaukahmbha Sanskrit Sansthan Varanasi.

\section{Source of Support: Nil Conflict of Interest: None Declared}

How to cite this URL: Sapna Maheshwari et al: Effect Of Perineal Repair And Mushakadi Taila Matrabasti In Management Of Rectal Prolapse (Gudabharmsa): A Case Study. International Ayurvedic Medical Journal \{online\} 2020 \{cited August, 2020\} Available from: http://www.iamj.in/posts/images/upload/4267 4270.pdf 